\title{
RESTRICTIONS OF THE FREEDOM OF SPEECH IN FRANCE IN THE DIGITAL TECHNOLOGIES ERA
}

\author{
Xenia A. Ivanova, Alexander A. Stepanov \\ Tyumen State University, Tyumen, Russia
}

\section{Article info}

Received - 2019 January 13

Accepted - 2019 February 25

Available online - 2019 April 20

\section{Keywords}

Right to freedom of opinion, freedom of speech, censorship, restrictions of the right, France, digital technologies, Internet, law enforcement
The subject. The article reveals an understanding of the freedom of speech in French law The purpose of the article is to identify the contents of freedom of speech in the French law and to determine the boundaries of its implementation in the Internet as well as to confirm or refute the hypothesis that both the freedom of speech and the definition of the boundaries of that freedom meets the purposes of protection of human rights.

The description of methodology. General scientific methods - analysis, synthesis, induction, deduction, comparison - were used. The authors also use the formal legal interpretation of French judicial decisions and content-analysis of press.

The main results and scope of their application. Freedom of speech is one of the foundations of French society, but it has become necessary to revise a number of rules governing freedom of speech and imposing restrictions due to widespread using of Internet in people's life. So exceptions from freedom of speech are embedded in national legislation, despite the fact that the basis for the legal regulation of freedom of the media in a democratic society is to ensure non-interference of the state in the content of production and dissemination of information. In some countries exceptions to freedom of speech are expressed primarily in the form of rules aimed at preventing abuses of freedom of the mass media and serving as a basis for sanctions against media editorial boards. The authors also cite actual examples of the realization of the freedom of speech in France, and draw conclusions about the possibilities for the development of this right. The proposed analysis may be used as a basis for improvement national legislation concerning limitations of freedom of speech.

Conclusions. Freedom of speech and freedom of the media are not absolute in France. In order to fulfil its function of protecting and guaranteeing rights and freedoms, the state must pay equal attention both to ensuring freedom of speech (including the independence of the press, access to information) and to defining the limits of this freedom in order to prevent its unlawful abuse. Any freedom turns into chaos without proper boundaries.

* This work was supported by the Russian Federation President Grant Council [MK-2440.2018.6.]. 


\section{Introduction.}

According to clause 1 of Article 10 of the European Convention on Human Rights "Everyone has the right to freely express his opinion. This right includes the freedom to hold opinions and the freedom to receive and impart information and ideas without interference from public authorities and regardless of state borders. This article does not prevent States from licensing broadcasting, television or cinema enterprises". According to the position of the European Court of Human Rights: "Freedom of expression is one of the fundamental foundations of a democratic society, one of the main conditions for its progress and development". Freedom of expression is determined by the fact that everyone has the right to express their opinions, ideas, communicate, but also has the right to access information.

The origins of freedom of expression go back to antiquity, when people could speak out in the Agora and speak during debates. However, only rich people and politicians had the right to speak. Thus, the universal formula of freedom of speech did not exist.

Now the right to freedom of speech is one of the fundamental human rights, without the realization of this right it is difficult to imagine a democratic state $[1$, p. 9]. However, in the modern technological world, in the era of the development of Internet space, this right is undergoing a transformation. There are such questions as: what is publicity, whether restrictions on the right to freedom of opinion are possible, especially in the network, how to determine the jurisdiction of the state in the network and others.

This article explores the development of the right to freedom of opinion in France. This experience is interesting for Russia, since France is a country of developed civil initiatives, and also because French law had a significant impact on the formation of Russian democracy.

In France, freedom of expression arises only during the 1789 Revolution. Article 11 of the Declaration of the Rights of Man and the Citizen, adopted by the National Constituent Assembly on August 26, 1789, states that "Free expression of thoughts and opinions is one of the most precious human rights; therefore, every citizen is free to speak, write, print, and is responsible only for the abuse of this freedom in cases provided by law".

About a century later, the law on freedom of the press was adopted on July 29,1881 . It is often regarded as a fundamental legal act in the field of press freedom and freedom of expression in France. Prior to its adoption, newspapers were subject to prior censorship: in 1811, only four newspapers remained in the country, and all of them were under state control. This law established a number of rights and guarantees for the press and abolished preliminary censorship, but at the same time, a regime of press responsibility for publications and the possibility of their control a posteriori. According to him, "the press should not cross certain borders, including in terms of the reputation and rights of others, however, it is obliged according to its functions to provide information and ideas on all matters of public interest, including issues related to the functioning of the judiciary system".

In the digital age, the law on press freedom applies to the Internet. After the attack on the editorial Charlie Hebdo in 2015 [2, p. 161] the French population constantly claims its freedom of speech and freedom of the press, whether in the press or in cyberspace [3].

With the development of the Internet, the French state had to adapt its legislation regarding freedom of expression in public space and censorship regime, since the Internet seems to be a threat to both the state and citizens. $[4 ; 5 ; 6]$.

In this regard, it seems reasonable to explore freedom of expression in France from the point of view of the following aspects: guarantees of the realization of this freedom, the form of its control by the state and society, as well as its existing boundaries.

\section{2. "Sacred Freedom in a Democratic Society".}

Freedom of expression is one of the foundations of French society. France has ratified most of the instruments relating to freedom of expression, such as the 1948 Universal Declaration of Human Rights (UDHR) and the 1969 International Covenant on Civil and Political Rights. For example, Article 19 of the UDHR provides that "Everyone has the right to freedom of opinion and expression; this right includes the freedom to freely adhere to one's convictions and the freedom to seek, receive and impart information and ideas by any means and regardless of state borders".

This article defines unrestricted freedom of expression and, although this declaration is ratified, it is not binding. France gives this issue a special character, since the views of minorities, as well as the intolerant opinions of individuals in the name of their freedom of expression, can be expressed both in public and in private space.

It is important to note that France supports the mandate of the Special Rapporteur on the promotion and protection of the right to freedom of opinion and expression, established in 1993. A salaried worker collecting e $r$ information on violations of freedom of 
ISSN 2658-4050 (Online)

expression and make recommendations to States so that they can best protect this freedom.

France is also subject to judicial control by the ECtHR in connection with the implementation of Article 10 of the European Convention on Human Rights, and in this regard it should best protect the freedoms contained in the Convention.

In the digital age, France had to adapt its legislation. Despite the fact that the press freedom law of 1881 was issued before the advent of the Internet, some of its provisions are applicable. The Internet is becoming a single space that goes beyond geographic boundaries, which is a problem for the state, as Web users can speak and access information beyond what is published.

In its report of 25 March 2010 the General Assembly of the United Nations allocates ten there are obstacles on the way to the second freedom of expression. In particular, in the field of the implementation of freedom of expression on the Internet, such problems are highlighted as: a) the fragmentation of the Internet through the introduction of filters and firewalls; b) government intervention, including the blocking of websites and domains on the Internet that provide access to social networks and usercreated content for social, historical and political reasons; c) jurisdictional rules that allow prosecution in any place, especially in the case of libel, and which encourage compliance with the lowest common denominator . In addition to these obstacles, the report emphasizes "the significant potential of the Internet as a means of facilitating the free flow of information and ideas that are not fully realized due to the desire of some states to control or limit the use of these media." From this point of view, France supported the Council of Europe in creating a platform to collect information about incidents involving journalists and the obstacles to this freedom on the Internet.

It can be said that the principle of freedom of expression symbolically led to the fact that no formalities were established for the Internet related to the declaration of Internet services for online services, which was confirmed in the law of June 21, 2004 on trust in the electronic economy. This law establishes the responsibility of hosting when it is informed of an illegal site. In this case, it should prevent users from accessing this page.

In the face of the expansion of social networks, France, like other countries, faced a new problem. Due to the fact that the Internet provides the possibility of anonymity, web users freely expressed in an aggressive form, including those containing hate speech or acts of cyberbullying $[7 ; 8]$. Take the example Ask.fm. After a series of threatening and mocking remarks, four French teenagers committed suicide. It was subsequently established that the fight against such threats is the responsibility of the state, and the site was released from liability.

In 2015, the French National Consultative Commission on Human Rights published an instruction on combating hate speech. Christine Lazarje, the chair of this commission, is concerned about "the spread of hate speech on the web, which is confronted with a lack of effective policies and tools applied in this area, as well as a number of effective legislative mechanisms" . The commission emphasized the outdated aspects of the 1881 press law, which did not adapt to the phenomenon of the Internet. A new central body was also proposed, which could be an extension of an existing body, such as the High Authority for the dissemination of works and protection of rights on the Internet, the National Commission for Informatics and Freedoms or the Supreme Council for Audiovisual Media.

In addition to a certain will to protect freedom of expression, there is a willingness on the part of the state to censor statements containing the rhetoric of intolerance.

\section{Censorship in the French state and society}

In France, there are several forms of censorship: preventive censorship (a priori), repressive censorship (a posteriori), and self-censorship, which is its highest form $[9 ; 10$, p . 63]

Preventive censorship is carried out before the publication of a newspaper or book. Thus, it is carried out arbitrarily, since there is no judicial authority to verify its necessity. It was abolished during the period of the French Revolution, but was restored under Napoleon in 1810 and again became the norm. [11, p . 13]. Press preventive censorship was re-abolished with the adoption of a law of July 29, 1881 on freedom of the press. But it was restored again under the Vichy regime, during which the so-called "Otto List" was established, which contained books forbidden by the Nazis. In part, this censorship is still relevant, since the law of 1949 a commission was set up to monitor and control publications intended for adolescents and children in order to prevent the publication of children's literature that promotes crime and a criminal lifestyle.

Gradually, it began to be repressed by repressive censorship, a form of censorship in which the court makes a decision after publication.

According to Emmanuel Pierrat: "The highest form of censorship is the emergence of self-censorship". 
Self-censorship is censorship practiced by oneself in relation to one's words, with the goal of anticipating possible censorship by the state. This new form of censorship restricts freedom of speech, as well as the right to information. His thought is developed by Magali Lötel: "self-censorship is the most cruel of censorship because it binds the thoughts of an author or a journalist." In fact, the journalist is forced to limit his statements so as not to be subject to judicial censorship or to protect himself from possible physical retaliation.

In this regard, it is important to recall how the caricature scandal on the Prophet acquired an international character, which resulted in the immediate self-censorship of the media. This incident took place on September 30, 2005, when the Danish newspaper " Jyllands-Posten " published twelve cartoons on the Prophet. This affected the Muslim community, which held multiple demonstrations. The reaction of some Muslim states (such as Jordan) was harsh and provided for sanctions against these journalists. Self censorship was absent because the journalists wanted to declare their freedom of speech.

In order to support, other publications were mobilized. In this regard, on February 8, 2005, Charlie Hebdo reproduced caricatures. The French Council of Muslim worship sued the newspaper. On September 12, 2006, the Paris Criminal Court rejected their application. Charlie Hebdo usually made caricatures of various religious movements. The publication was threatened by religious groups and, therefore, enjoyed increased protection. But in 2015 they were victims of a terrorist attack, which killed the main authors of the newspaper.

According to Florent Latriva: "The Internet seems to be emptying from its very essence the very idea of censorship" [4, p. 98]. It appears that the French government is faced with such problems, as the uncontrolled proliferation of certain documents subject to censorship, sites with illegal content, or distribution sites of terrorist orientation .

Some authors have wondered if there is a "French exception" in the field of the Internet? The global nature of the Internet gives rise to conflict of laws problems, such as Yahoo's case. So, the American company Yahoo Inc., based in the United States, established the French subsidiary of Yahoo France. Yahoo Inc. was accused of placing in the search results of the site offering the purchase of items with Nazi symbols, to which the French could have access from the English version of the site, but not from the French. The Paris High Court appeals to Yahoo France and Yahoo Inc. with the requirement to make the requests "negationism" and "holocaust" inaccessible to users from France. French judge in two decisions in 2000 once again confirmed its jurisdiction and gave Yahoo Inc. a three-month period to make these requests impossible with Yahoo.com.

At the same time, on the other side of the Atlantic, the court of San Jose (California) sided with Yahoo Inc. and November 7, 2001 it was decided to "violation of the French decision of the First Amendment to the US Constitution, and hence the impossibility of execution of the decision in the United States." However, in its decision of 23 August 2004 the Court of Appeals 9th District of California overturned the the decision, stressing that the first amendment to the United States Constitution should not apply to a foreign decision, the application of which was not requested by any court.

Relatively recently, the law of November 13, 2014 established a "mechanism to block administrative access to sites containing terrorist propaganda". This law is a preventive censorship of state bodies, since they can interfere in the process after the publication of such a page. As for Internet providers and hosting providers, they are still required to be vigilant. The law included a new article 6-1 in the law on trust in the field of electronic economics, which provides for a step-by-step site removal procedure.

The French authorities continue to strive to ensure the accountability of Internet providers and hosting providers. There is a clear doubt about the requirements of the ECtHR regarding restrictions on freedom of expression. The court recognizes the protection of national security by limiting, but he defends facts or ideas that do not contain "destructive consequences" or do not require immediate violence. Under conditions of such censorship, freedom of expression is significantly restricted.

\section{Restrictions in order to protect the state and} society .

Freedom of expression is not unlimited, since "French law has always recognized that freedom of expression must be consistent with other freedoms or rights of equal value" [13]. If we analyze each normative act concerning this freedom, then it will be limited almost everywhere. Thus, Article 10 of the European Convention on Human Rights states in paragraph 1 that "everyone has the right to freely express his opinion", but it is limited in paragraph 2 of Article 10 of the Convention: "The exercise of these freedoms, imposing duties and responsibilities, may be associated with certain formalities, conditions, restrictions or sanctions that are provided for by law and are necessary in a democratic society in the interests of national security, territorial 
ISSN 2658-4050 (Online)

integrity or public order, in order to prevent riots or crimes, to protect health and morals, to protect the reputation or rights of others, to prevent the disclosure of information received in confidence, or ensuring the authority and impartiality of justice. " Thus, a state can create the limits of this freedom if it observes the requirements of the Convention.

In its judicial practice, the ECtHR stands on the side of both the state and individuals. So, in the case of "Garaudi v. France" the court found that the work of the applicant, calling into question the existence of Nazi crimes against humanity, is "of a serious negative nature and contradicts the fundamental values of the Convention, namely justice and peace" .

In another case, on July 13, 1984, an announcement was published in the Le Monde newspaper, which read "French, you have a short memory", followed by the mention "Philippe Petain, June 17, 1941". The defendants were found guilty of justifying terrorism by the Court of Cassation. The ECHR considered the sanction "disproportionate and, therefore, unnecessary in a democratic society". At the same time, no violation of Article 10 of the ECHR was found.

The Press Freedom Act of 1881, which seems to be liberal, according to Bertrand de Lamy, is basically a repressive law, but with the goal of protecting people [8]. The law contains chapter IV, entitled "Crimes and offenses committed by the press or by any other means of publication", which rejects all existing prohibitions in this area. Some of these restrictions were enforced in accordance with the Act of July 13, 1990 criminalizing any discrimination based on membership of an ethnic group, nation, race or religion. Michel Troper emphasized that "these theses may threaten to consider interests, such as freedom of expression itself, one of the most important human values. In addition, they threaten not just its expression, but actions to which it can lead and with which it forms a single whole" [14, $p$. 240].

The law on trust in the field of electronic economics also provides that the law of Geysotta is valid for all publishers on the Internet. It is on this issue that the Court of Cassation in its judgment of June 19, 2008 confirmed the possibility of stopping access to the AAARGH website, where revisionist theses were collected. Indeed, Article 6-1.8 of the Law on Trust in the Field of Electronic Economy provides that a judicial authority may prescribe, by way of simplified proceedings or on the basis of a statement of claim, the hosting provider or Internet provider any measures aimed at preventing damage or stopping damage, caused by site content.

The restrictions imposed reflect the genuine willingness of the state to stop any damage to the public interest. In conclusion, we can say that freedom of expression is not perceived by the French legislator as full and unlimited, since there are restrictions for the protection of the state and citizens.

\section{Conclusions.}

The rights and freedoms of citizens in French constitutional law are fixed rather peculiarly [15, p. 51]. The basic law of 1958 does not have a special section or chapter on rights and freedoms. Here there is only a reference rule in the preamble to the Declaration of the Rights of Man and the Citizen of 1789, supplemented by the preamble of the Constitution of 1946. In the text of the Constitution, rights and freedoms are contained only in a few isolated articles: the principle of equality before the law of all citizens is confirmed, regardless of origin, race or religion (Article 2 ), the character of the Republic is recognized as indivisible, secular, democratic and social (hence general conclusions on the nature of human rights), speaks of sovereignty and the right to vote, of pluralism of political parties and respect for democratic principles (Articles 3 and 4). In addition, Article 34 regulates the establishment of rules relating to civil rights and freedoms to the sphere of law, Article 53 speaks about the right of peoples to self-determination, Articles 64 and 66 - about the independence of the judiciary as the guarantor of rights and freedoms.

At the same time, a positive point is the calm attitude of the French towards the necessary measures to restrict the freedom of speech. Unfortunately, the closeness of Soviet society predetermined the disequilibrium ratio of the information freedom of the society and its information security, the human right to information and his right to protection from information, freedom of speech and the duty not to exercise it to the detriment of the legitimate rights and interests of others. Any attempts by the state to bring the permissiveness of freedom of speech into the legal framework immediately provoke fierce protests. The French have already partially overcome this gap between the expectations of society and the state, as evidenced by the practice described in the article on the legal application of restrictions of this right.

Even a completely democratic European Convention for the Protection of Human Rights and Fundamental Freedoms establishes that the exercise of the freedom of expression and the freedom to receive information, "imposing duties and responsibilities, may 
be associated with certain formalities, conditions, restrictions or sanctions that are provided by law and are necessary in a democratic society in the interests of national security, territorial integrity or public order, in order to prevent disorder and second, for the protection of health or morals, for the protection of the reputation or rights of others, for preventing the disclosure of information received in confidence, or for maintaining the authority and impartiality of the judiciary "(it. 2, Art. 10).

Thus, it is clear that freedom of speech and freedom of the media is not absolute. Neither society nor a person should be held hostage to these freedoms, and their implementation should have limits established by law. It seems that in order to fulfill its function of protecting and guaranteeing rights and freedoms, the state should equally pay attention to ensuring freedom of speech (including press independence, access to information) and defining the scope of this freedom in order to prevent illegal abuse. it, i.e. violation of other rights and interests protected by law. Without appropriate boundaries, any freedom turns into chaos. 


\section{REFERENCES}

1. Bykhovskaya E. Right to freedom of expression in TV-broadcasting in the practice of the Inter-American Court of Human Rights. A commentary to the Judgment of the IACHR of 22 June 2015 in the Case of Granier and others (Radio Caracas Television) v Venezuela. Mezhdunarodnoe pravosudie = International Justice, 2017, no. 1, pp. 3-13. (In Russ.).

2. Kazantseva N.V. Prevention of crimes against freedom of conscience, Cand. Diss. Moscow, 2017. 268 p. (In Russ.).

3. Ségur Ph. Terrorism and freedoms on the Internet. L'Actualité Juridique Droit Administratif, 2015, no. 3, pp. 160-165. (In French).

4. Latrive F. The Internet, in: Pierrat E. (dir.). Le livre noir de la censure. Paris, Seuil Publ., 2008, pp. 95-122. (In French).

5. Mallet-Poujol N. Freedom of expression on the internet: aspects of domestic law. Recueil Dalloz, 2007, no. 9, pp. 591-599. (In French).

6. Ségur Ph., Périé-Frey S. The Internet \& Digital Democracy. Perpignan, University of Perpignan Publ., 2016. 220 p. (In French).

7. Ivanova K.A., Stepanov A.A., Nemchinova E.V. Cyberbullying as a Deviation of the Right of Citizens to Freedom of Opinion on the Internet. Aktual'nye problemy rossiiskogo prava = Actual Problems of Russian Law, 2019, no. 1, pp. 96-101. DOI: 10.17803/1994-1471.2019.98.1.096-101. (In Russ.).

8. De Lamy B. Freedom of opinion and criminal law. Revue internationale de droit comparé, 2001, Vol. 53, no. 4, pp. 1023-1024. (In French).

9. Duverger E., Ménard R. Censorship of the right-thinking. Paris, Abin Michel Publ., 2003. 164 p. (In French).

10. Lhotel M. Self-censorship, in: Pierrat E. (dir.). Le livre noir de la censure. Paris, Seuil Publ., 2008, pp. 63-94. (In French).

11. Pierrat E. Forms of censorship, in: Pierrat E. (dir.). Le livre noir de la censure. Paris, Seuil Publ., 2008, pp. 1162. (In French).

12. Marzouki M. New ways of censorship: the case of the Internet in France. Le temps des médias, 2003, no. 1, pp. 148-161. (In French).

13. Zoller E. Freedom of expression in the United States and Europe. Paris, Dalloz Publ., 2008. 292 p. (In French).

14. Troper M. The Gayssot Act and the constitution. Annales. Histoire, Sciences Sociales, 1999, vol. 54, no. 6, pp. 1239-1255. (In French).

15. Mishin A.A. Constitutional (state) law of foreign countries, 16th ed. Moscow, Yustitsinform Publ., 2010. 559 p. (In Russ.).

\section{INFORMATION ABOUT AUTHORS}

Xenia A. Ivanova - PhD in Law, Associate Professor, Department of Constitutional and Municipal Law, Institute of State and Law Tyumen State University 6, Volodarskogo ul., Tyumen, 625003, Russia e-mail:k.a.ivanova@utmn.ru RSCI SPIN-code: 6610-9218; AuthorID: 695216

Alexander A. Stepanov - Master's Student, Institute of State and Law Tyumen State University 6, Volodarskogo ul., Tyumen, 625003, Russia e-mail: a.a.step@bk.ru

\section{BIBLIOGRAPHICDESCRIPTION}

Ivanova X.A., Stepanov A.A. Restrictions of the freedom of speech in France in the digital technologies era. Pravoprimenenie $=$ Law Enforcement Review, 2019, vol. 3, no. 1, pp. 15-23. DOI: 10.24147/2542-1514.2019.3(1).15-23. (In Russ.). 